\title{
The development and validation of the GI-ALE instructional model for the emerging collective intelligence of the scientifically gifted student
}

Kyunghee Jeon ${ }^{1}$, Dahye Park ${ }^{2}$ and Jongseok Park ${ }^{3 *}$

\footnotetext{
* Correspondence: parkbell@knu.ac. $\mathrm{kr}$

${ }^{3}$ Kyungpook National University, Daegu, South Korea

Full list of author information is available at the end of the article
}

\begin{abstract}
This research aims to develop an instructional model using advanced laboratory equipment (ALE) based on collective intelligence attributes that can be applied to the scientifically-gifted students. The developed GI-ALE model is defined by introducing the principles of the group investigation (Gl) model to the existing ALE instructional model based on the factors of six types of collective intelligence: shared vision and value formation, knowledge in specific areas and diversity in those areas, knowledge sharing system, dynamism through decentralization and integration, and synergy effect. After deriving the learning design principles from the attributes of the six types of collective intelligence, the specific teaching and learning elements have been extracted. The GI-ALE model consists of seven steps: announcing learning goals, organizing groups and subtopics, preparing an experimental plan, preparing preliminary reports, the presentation of pre-report written in group unit, experimenting, creating report in group unit, and sharing and evaluating the outputs. It was applied to 76 students in a chemistry experiment lesson engaged in the second-grade curriculum at a Science High School. From qualitative data obtained after model application, this model helped students to acquire advanced scientific experimental skills and various types of knowledge. It has been also confirmed that the students experienced dynamic interactions and decentralized leadership as required by collective intelligence in the process of sharing and integrating professional experimental knowledge. In addition, the students had many opportunities for individual and collective reflection through open self-directed learning. By using one device on a variety of topics with their colleagues through group activities, they had the confidence to utilize it individually. The GI-ALE instructional model also helped scientifically-gifted students to deepen their scientific inquiry level. This model will encourage the gifted students to be able to explore the real world, to learn the attributes of collective intelligence, and to produce knowledge autonomously.
\end{abstract}

Keywords: Scientifically-gifted education, Collective intelligence, Group investigation, Scientific inquiry, Advanced laboratory equipment, Gl-ALE instructional model 
초록

과학영재 교육의 목적은 학생들이 실제 세계에 대해 자율탐구를 수행할 수 있 도록 지도하는 것이다. 그러나 과학고 학생들이 정규교육과정 안에서 자율탐구 를 수행할 수 있도록 도울 수 있는 체계적인 교수학습 전략에 대한 연구가 미흡 한 실정이다. 이에 이 연구에서는 학생들의 자율탐구 역량을 강화시킬 수 있도 록 과학고에 적합한 수업 모형을 개발하고자 하였다.

과학적 창의성은 선천적으로 타고 나는 능력이 아니라 배우고 계획할 수 있기 때문에 특정 집단이 어떤 프로세스를 거치냐에 따라 집단의 창의력 성과는 달 라질 수 있다. 그러므로 이 연구에서는 과학고 학생들에게 과학탐구를 어떻게 지도할 것인가에 대한 방향성을 집단지성의 개념에서 찾았다. 과학영재를 위한 수업모델로서 집단지성의 속성을 기반으로 첨단과학 실험기기를 활용한 수업 모델을 제안하고 그 타당성을 살펴보았다. 이 수업모델은 기존에 연구된 ALE 수업전략에 협력학습의 모형인 집단탐구(GI) 모형의 원리를 도입하여 개발된 것으로, GI-ALE 수업모형으로 정의하였다. 공동의 비전과 및 가치 형성, 특수영 역에서의 지식, 그 영역에서의 다양성, 지식공유시스템, 분산화와 통합을 통한 역동성, 그리고 시너지 효과의 6가지 집단지성의 속성을 바탕으로 교수학습 요 소를 추출하였다. 이 수업모델은 학습목표 제시, 집단 구성 및 하위주제 선정, 실험을 위한 자료 수집 및 탐구계획 수립, 모둠 단위의 사전보고서 발표, 탐구 수행, 모둠 단위의 최종 실험보고서 작성, 학습결과물 공유 및 평가의 7단계로 이루어졌다. 대구 D과학고 2학년 4개반 76명의 학생을 대상으로 화학실험 수업 에 GI-ALE 수업 모형을 적용하였으며, 이를 통해 수업모델의 타당성을 위한 질 적 자료로 수집하였다. 질적 자료를 분석한 결과, 이 수업은 학생들에게 수준 높은 과학적 실험 기술과 그에 따른 다양한 지식을 습득하는 데 도움이 되었다. 학생들은 전문적인 실험적 지식을 공유하고 통합하는 과정에서 역동적인 상호 작용, 분산화된 리더십을 경험하였음을 확인하였다.그리고 학생들은 자기주도 성이 발휘되는 개방적 학습을 통해 개인 및 집단성찰에 대한 기회를 많이 가졌 으며 집단탐구 활동을 통해 하나의 실험기기를 다양한 주제에 활용해봄으로써 혼자서도 기기를 다른 주제에 활용할 수 있는 자신감이 형성된 것을 살펴볼 수 있었다. 이처럼 첨단과학 실험기기를 활용하는 전문지식을 공유하고 습득하는 학습은 과학영재들에게 실생활에서 발견할 수 있는 문제를 검증 가능한 과학 적 문제로 구체화시켜 나갈 수 있는 발판을 마련해 줄 수 있을 것이다. 또한 과 학영재들에게 과학을 선도하는 집단지성인으로 성장할 수 있는 역량을 키우며 과학고 본연의 정체성을 확립시켜 줄 수 있을 것이다.

주요어: 과학영재 교육, 집단지성, 집단 탐구, 과학적 탐구, 첨단과학 실험기기, GI-ALE 수업 모형

\section{Introduction}

It has recently been seen that not just experts, but also the general public, have been contributing to the production of knowledge in every day life. This knowledge is produced in the form of many different kinds of photos, text, and videos that the public shares on the internet in places such as blogs, Facebook and YouTube. While the public had previously only played the role of knowledge consumers, the production of knowledge is being redistributed from the domain of experts to the general public thanks to the portals and search sites that have emerged during the transition of the medium of knowledge acquisition from mass media to the internet (Han 2009).

The public as the knowledge producers go a step further to jointly produce knowledge through, for example, Wikipedia and Social Networking Services (SNS). These are referred to as Web 2.0. Contributions to the production of public knowledge by groups of people have shown that groups of people, when working together, can often 
make wiser judgments than an individual member in isolation (Surowiecki 2005). Based on this concept, many companies encouraged a process of having their members freely exchange ideas and opinions which has allowed to the development of some brilliant ideas and resulted in many innovations (Sawyer 2011). These outcomes show the importance of group-based activities that obtain success through a continuous exchange of information, mutual cooperation, and trial and error.

Lévy (1994a, 1994b) first named these group-based activities collective intelligence. He defined collective intelligence as "a form of universally distributed intelligence, constantly enhanced, coordinated in real time, and resulting in the effective mobilization of skills" (p. 13) and then discussed collective intelligence in society as a whole, including ethics and economics (Lévy 1994a, 1994b). Since then, most of the follow-up studies related to collective intelligence have been in the field of business management related to companies (Leadbeater 2009; Pór, 1995; Surowiecki 2005).

In Korea, the study of collective intelligence has been focused on the possibilities for educational use based on the Internet, and several studies have been conducted in the field of education (Kim and Kim 2011). There have been studies about collective intelligence as a theoretical approach, including a study on the conceptual model of collective intelligence and its design principles (Lee and Lee 2009), studies on the characteristics of collective intelligence and the exploration of educational implications through the verification of organizational systems (Jeon 2013; Lee 2013; Yang 2010, 2011), in addition to a study on the development of a measuring tool for collective intelligence (Song 2016). There have been studies about collective intelligence for practical applications, including the development of a program to utilize collective intelligence, including a classroom model of collective intelligence that integrates onand off-line applications (Kim and Kim 2011; Kim 2014; Lee 2011).

In the field of science education, there have been recent studies on recognizing the educational importance of collective intelligence, determining scientific knowledge formation processes (Kim et al. 2013), and developing programs based on the principle of collective intelligence (Lee et al. 2014, 2015). Kim et al. (2013) found there to be educational significance in that the research provided implications for the development of classes using collective intelligence by identifying the stages in which knowledge was formed by the pre-service teachers. However, this did not lead to direct program development. Thus, the development of a science class program based on the principle of collective intelligence has recently emerged (Lee et al. 2014, 2015). However, the program is focused on instructional models for Socio-Scientific Issues (SSI), thus it is required that the programs related to inquiry, which are the core of science, is developed.

Applying collective intelligence to education is not easy. The prerequisite for collective intelligence to emerge is that the group must consist of people with a variety of knowledge and insights (Surowiecki 2005). Therefore, it is difficult to create collective intelligence in the true sense of "creating knowledge as a group" in an ordinary school consisting of students from various backgrounds and knowledge levels. Groups where collective intelligence can emerge include teachers or pre-service teachers who majored in science education. Some studies have been conducted on these groups (Kim et al. 2013; Lee et al. 2015). However, there has been no collective intelligence study involving gifted students at a science education high school. In addition, the question of whether it is worth applying the concept of collective intelligence for educational use 
has been raised, with critics saying that so far, the direction of collective knowledge production education in pedagogy has only ben a new form of web bulletin board with a simple form of adding comments (Kim and Kim 2011; Kim et al. 2010). Thus, science education requires theoretical research on collective intelligence, not in the form of traditional web bulletins, but on teaching and learning model research that embodies it.

Knowledge production in science education is made through inquiry. At the center of inquiry is experimentation. High-level inquiry, especially for gifted students, requires a lot of time and a variety of experimental devices. In this respect, South Korea's science high schools are one of the most suitable places for the inquiry learning of gifted students. Science high schools are Korea's secondary educational institutions for science gifted education, which provides differentiated education programs specialized in science by selecting based on the students' particular scientific giftedness. Science high schools have the particular advantage of being equipped with the most advanced scientific experimental devices in order to utilize the research and performance techniques of real scientists (Jeon et al. 2016). As a result, the advanced laboratory equipment (ALE) utilization strategy has already been developed, and its effectiveness has been demonstrated (Jeon et al. 2016).

Thus, a program for helping collective intelligence to emerge that can be applied to science high school students involves implementation by applying a group investigation (GI) model to a high-tech experimental device education program. Collective investigation is defined as a scientific process or method that creates a classroom environment where students can actively explore the unknown world to find relevant knowledge (Thelen 1960). It is very suitable for revealing collective intelligence in science subjects.

The purpose of this study is to develop a group investigation-advanced laboratory equipment (GI-ALE) model, namely in the form of a class that utilizes high-tech experimental devices for gifted students, by theoretically revealing the attributes of group intelligence applicable to science education through the analysis of prior research studies of collective intelligence. Through these efforts, this study aims to provide a model of collective intelligence suitable for science education and to apply it to gifted students to help creativity and to encourage collective intelligence to emerge.

\section{Research method}

In order to develop the GI-ALE instructional model, the factors of collective intelligence in science education were identified by extracting and re-structuring collective intelligence-related elements through analysis of previous research. Based on this, teaching strategies for the development of the GI-ALE instructional model were derived, and then the GI-ALE instructional model was embodied and applied to the students in order to modify and supplement the developed model.

To extract the attributes related to collective intelligence, precedent studies were suggested as having content related to collective intelligence, including the Lévy (1994a, 1994b), who first mentioned collective intelligence (Hill et al. 2014; Lee and Lee 2009; Sawyer 2011; Surowiecki 2005; Leadbeater 2009). The clear attributes of collective intelligence, such as decentralization and coordination (Surowiecki 2005), have been presented in previous studies and accepted. Two researchers read each of the previous studies and they organized the related factors and discussed and solved any disagreements they had about these factors. 
The two researchers then classified the attributes of collective intelligence from the other previous studies based on the conceptual design principles of collective intelligence for educational application as proposed by Lee and Lee (2009). Based on these classified attributes, 6 factors for collective intelligence in gifted science education on reflection the specificity of science gifted education have been reconstructed. In cases of disagreement, several discussions were conducted to reach a consensus between the two researchers. In particular, there was a lot of discussion on how to define the concept of synergy effect in education. As a result, the synergy effects can be linked to assessment in the learning process. In other words, we discussed for a long time on how to evaluate students' outputs based on the attributes of collective intelligence and how to integrate the output of each subgroup to produce knowledge for the entire group.

The principles that can be used to apply collective intelligence educationally have been explored using the concept of collaborative learning (Yang 2011). The instructional strategies were derived based on the six factors for collective intelligence reorganized earlier. This was revised and supplemented through discussion at an expert group seminar with two science education experts and three incumbent teachers. The members of the group in the seminar then completed the actual applicable instructional model.

In this study, among the chemistry laboratory equipment, the experimental topics involved the use of UV-Visible spectrometer and IR spectrometer. This is because the devices can be used for various topics generally. Therefore, since four subgroups are formed in a class, four topics must be met per device. These 4 subtopics are performed simultaneously by 4 subgroups throughout the seven GI-ALE lessons on a particular device. The content of the chemistry experiment textbook was reconstructed for the GI-ALE classes, which was developed focus on UV-Visible spectroscopy and IR spectroscopy. The content that was deemed more necessary used the material collected by the teacher. The corresponding experiments were the IR spectrum analysis of the surrounding polymer and the principles of the $\mathrm{TiO}_{2}$ photocatalyst reconstructed from Lim et al (2011). Table 1 shows 4 subtopics per device.

This GI-ALE class consisted of seven steps for chemistry experiments in regular classes. In the first lesson, orientation was given to guide the experiment. The other six lessons were conducted three times per week for $2 \mathrm{~h}$ each in order to present a large topic including utilizing the UV-Visible spectrometer for various inquiry topics, organizing the groups and the 4 subtopics presented, preparing the experimental plan, preparing preliminary reports, the experiment, writing reports, and sharing results. This model was constructed through several seminars, and external validation was achieved through field application.

It was applied to 76 students in the D Science High School in D City in a three-credit chemistry experiment lesson in the second-grade high school curriculum. In Korea, there are 20 science high schools established with the special purpose of educating scientifically-gifted students in the field of mathematics and science. These schools have excellent facilities with a lot of high-tech scientific equipment such as electron microscopes and various spectroscopy equipment. All of them are boarding schools. In

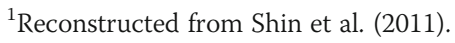


Table 1 Reconstruction of chemistry experiment topics for Gl-ALE classes

\begin{tabular}{lll}
\hline Advanced laboratory equipment & Content of experiment & Source \\
\hline FT-IR spectrometer & IR spectrum analysis of surrounding polymer & $\begin{array}{l}\text { Materials made by teacher } \\
\text { Device manual }\end{array}$ \\
& Synthesis of aspirin & Textbook \\
& Synthesis of nylon and polyester & Textbook \\
& Synthesis of nitrobenzene & Textbook \\
& Reaction of vitamin C with methylene blue & Textbook \\
UV-VIS spectrometer & Extraction and Identification of Caffeine & Textbook \\
& Principle of photocatalyst of $\mathrm{TiO}_{2}$ & Materials made by teacher \\
& Transition metals and coordination compounds & Textbook \\
\hline
\end{tabular}

addition, there are eight gifted schools created by Act on the Promotion of Education for those gifted and talented in the field of law.

During the course of GI-ALE, the teacher recorded the activities of the subgroups, and the qualitative data were collected through the final group report as a learning outcome and in-depth interviews with students when necessary. After applying the model, It was conducted an open-ended questionnaire with the students on GI-ALE classes. The content was to describe in detail the most difficult things and the things that helped the students, when doing two projects with spectroscopy. Through several seminars on the collected qualitative data, we found appropriate statements expressing the factors for collective intelligence. Also, in the open-ended questionnaire response to the GI-ALE lesson, even though the specific statements differed, the similar semantics were treated as a single answer, followed by classification according to the factors for collective intelligence.

\section{Results and discussion}

\section{Development of GI-ALE instructional model}

Collective intelligence has an educational implication in that it can allow for the realization of a learner-centered classroom. This is since the members start voluntarily working on the premise that the participation must occur constantly. This is because the interactions between various people-rather than the independent performance of an individual—can lead to new and diverse thinking. It can provide individuals with the opportunity to reflect on their thinking processes. The attributes related to collective intelligence as they apply to science education have been summarized in Table 2.

Lévy's (Lévy 1994a, 1994b) study has significance in that collective intelligence is defined for the first time. However, its scope is too broad to be directly applied to science education because it discusses collective intelligence in society as a whole in areas such as ethics and economics. Hill et al. (2014), Leadbeater (2009), Sawyer (2011), and Surowiecki (2005) also discussed collective intelligence and its attributes as related to business and the economy. However, Lee and Lee's (2009) study is closer to science education in that it presents the attributes related to the educational application of collective intelligence.

To summarize the collective intelligence-related attributes proposed by various scholars, the group shares the vision and values of the group and pursues the 
Table 2 Attribute related to collective intelligence

\begin{tabular}{|c|c|c|}
\hline \multirow{2}{*}{$\begin{array}{l}\text { Prior } \\
\text { research } \\
\text { Lévy } \\
\text { (1994a, } \\
\text { 1994b) }\end{array}$} & \multicolumn{2}{|c|}{ Attributes related to collective intelligence } \\
\hline & $\begin{array}{l}\text { Definition of collective } \\
\text { intelligence }\end{array}$ & $\begin{array}{l}\text { Form of universally distributed intelligence, enhanced } \\
\text { constantly, coordinated in real time, resulting in the effective } \\
\text { mobilization of skills }\end{array}$ \\
\hline $\begin{array}{l}\text { Surowiecki } \\
(2005)\end{array}$ & The wisdom of crowds & Diversity, independence, decentralization, coordination \\
\hline \multirow[t]{2}{*}{$\begin{array}{l}\text { Leadbeater } \\
\text { (2009) }\end{array}$} & $\begin{array}{l}\text { Five principles of collective } \\
\text { intelligence project success }\end{array}$ & $\begin{array}{l}\text { Core, contribute, connect (make relationships), collaborate, } \\
\text { create }\end{array}$ \\
\hline & $\begin{array}{l}\text { Optimization conditions of } \\
\text { collective intelligence }\end{array}$ & $\begin{array}{l}\text { Core group, stimulate challenging needs, feedback from peer } \\
\text { verification, differentiation of tasks by modules, clear rules for } \\
\text { selecting ideas, sharing of project ownership }\end{array}$ \\
\hline $\begin{array}{l}\text { Sawyer } \\
\text { (2011) }\end{array}$ & $\begin{array}{l}\text { Seven key characteristics of } \\
\text { effective creative teams }\end{array}$ & $\begin{array}{l}\text { Innovation emerges over time, deep listening, team members } \\
\text { build on their collaborators' ideas, do not hurry to define the } \\
\text { meaning of an idea, excellence in discovering new problems, } \\
\text { innovation is inefficient (produce endless ideas), innovation } \\
\text { emerges from the bottom up (start with a little improvised } \\
\text { idea) }\end{array}$ \\
\hline $\begin{array}{l}\text { Lee and } \\
\text { Lee (2009) }\end{array}$ & $\begin{array}{l}\text { Six components of collective } \\
\text { intelligence }\end{array}$ & $\begin{array}{l}\text { Shared mental model, collaborative intelligence, social } \\
\text { networking, diversity, collective memory system, integrated } \\
\text { group performance }\end{array}$ \\
\hline $\begin{array}{l}\text { Hill et al. } \\
\text { (2014) }\end{array}$ & Collective genius & $\begin{array}{l}\text { Purpose (why we exist), shared values (what we agree is } \\
\text { important), rules of engagement, creative abrasion, creative } \\
\text { resolution (creative reinterpretation), creative agility }\end{array}$ \\
\hline
\end{tabular}

knowledge and diversity in the specific domain of a given professional field. Collective intelligence builds a system that shares the knowledge produced by the group, accumulates data, and produces synergistic effects by producing useful output through the process of decentralization and integration. In other words, collective intelligence means the ability of the group to synthesize something that is more than the sum of the individuals' knowledge. The practice of creativity depends on the competency of the group. Some groups have settled on this capacity and gained a competitive edge (Kao 1997).

As noted earlier, Lee and Lee (2009) presented six attributes for the educational application of collective intelligence. Accordingly, based on these components, the collective intelligence-related factors of previous studies were also classified. In addition, we extracted the factors for developing collective intelligence that reflected the specificity of science gifted education. The six factors for collective intelligence that emerged have been presented in Table 3.

First, collective intelligence has a shared vision and shared values. If the members of the group clarify the common goal and share a vision and values, then the group is more likely to experience immersion (Sawyer 2011). Dynamic interactions within the team can lead to successful cooperation (Sharan 2010). Therefore, presenting a common vision and value to students will be a very important factor. Second, it has domain-specific knowledge. In previous studies, the research was conducted on companies and universities. The members were experts who had education, training, and experience. The knowledge discussed in collective intelligence is specialized, so it deals with knowledge in a specific domain. Science gifted education emphasizes inquiry learning, so domain-specific knowledge is more important than other subjects in experimental skills. Csikszentmihalyi (1999) also argues that creativity occurs as a result of interrelationships occurring within a system made of a person, a domain of 


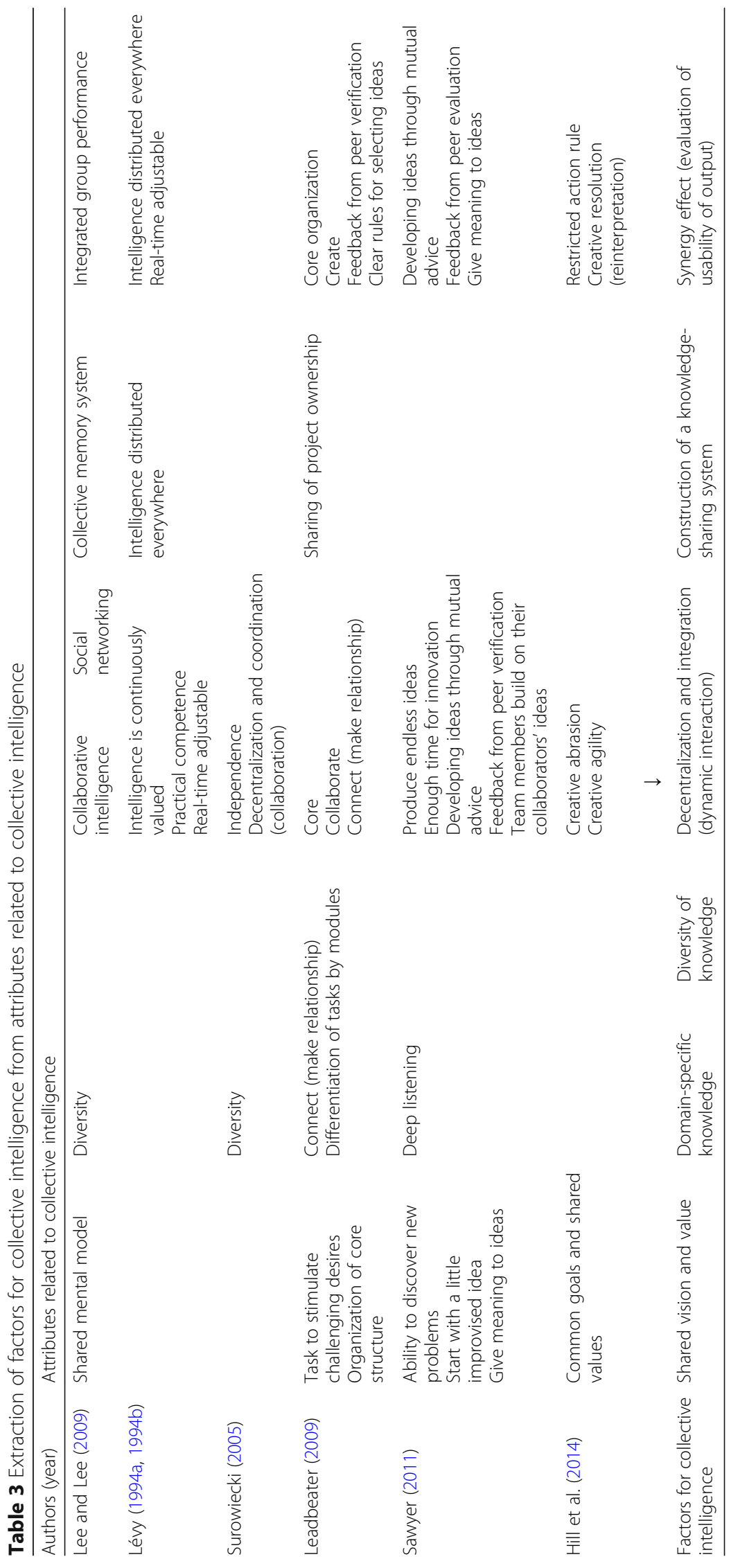


knowledge and a field. Science gifted education at high school level and the attributes of collective intelligence are based on expertise, thus the domain-specific knowledge was set as a component for developing collective intelligence.

Third, cognitive diversity is needed. This is because approaching the problem situation from various perspectives can extend the scope of the solution. This requires a great deal of experience and knowledge, especially when solving complex and real problems. By establishing an appropriate relationship with a variety of people, it is possible to then grasp a variety of information and to establish a foundation for new ideas. The principle of this relationship is also related to the dynamic interactions presented below.

Fourth, there should be dynamic interactivity through decentralization and integration. In particular, the members need to recognize that constructive debate is an effective activity that generates ideas. An innovative organization has creative conflicts that are dealt with based on a mutual respect and trust-based culture among members (Hill et al. 2014). Therefore, in order to create dynamic interactions, it becomes very important to establish relationships based on the trust between the members. Social networking is related to the degree of interconnectivity among members, for example, the use of SNS tools to enable the members to communicate and share information easier and faster (Lee and Lee 2009). Successful teams tend to spend less time in the planning phase and more in the action phase, which leads to more innovative performance (Sawyer 2011). This is because we are able to create an increasingly better solution as we continue to see if any given solution really works. Therefore, it is necessary for experimenters to recognize that they are learning something even if the experiment produces negative results.

Fifth, it is necessary to construct a system that facilitates access to knowledge when necessary. This system needs to accumulate useful data continuously so that it can be shared. As Leadbeater (2009) mentioned, with regard to collective intelligence project success requirements, sharing ideas can only occur if the ownership of the project is shared. Sharing knowledge in group is very important factor for collective intelligence. In other words, group integration is the ability to share, exchange, and combine the ideas and knowledge that exist within a group. Therefore, the group must have a system for sharing knowledge.

Sixth is the synergy effect. The synergy involved in collective intelligence is related to evaluation of the usability of the output, usually by internal or external evaluation. However, given that the concept of collective intelligence originates in the enterprise, there is a limitation in evaluating the usefulness of output when this applied to education. In the process of integrating the outputs of subgroups, students evaluate the outputs of other subgroups and reflect on their own products. So the synergy effect when applied in education is to elaborate knowledge through dynamic interactions and to learn the complicated a professional knowledge produced by the group.

The components for the development of collective intelligence are consistent with the flow of learning (Fig 1). Therefore when the teacher designs the lesson, it can be applied to the lesson considering the factors for collective intelligence.

One method of collaborative learning introduced by Sharan and Sharan (1976, 1990, 1992), is called the GI model. The GI model is suitable for preparing a collaborative system because the classroom is reorganized as a "group of subgroups" that induces 


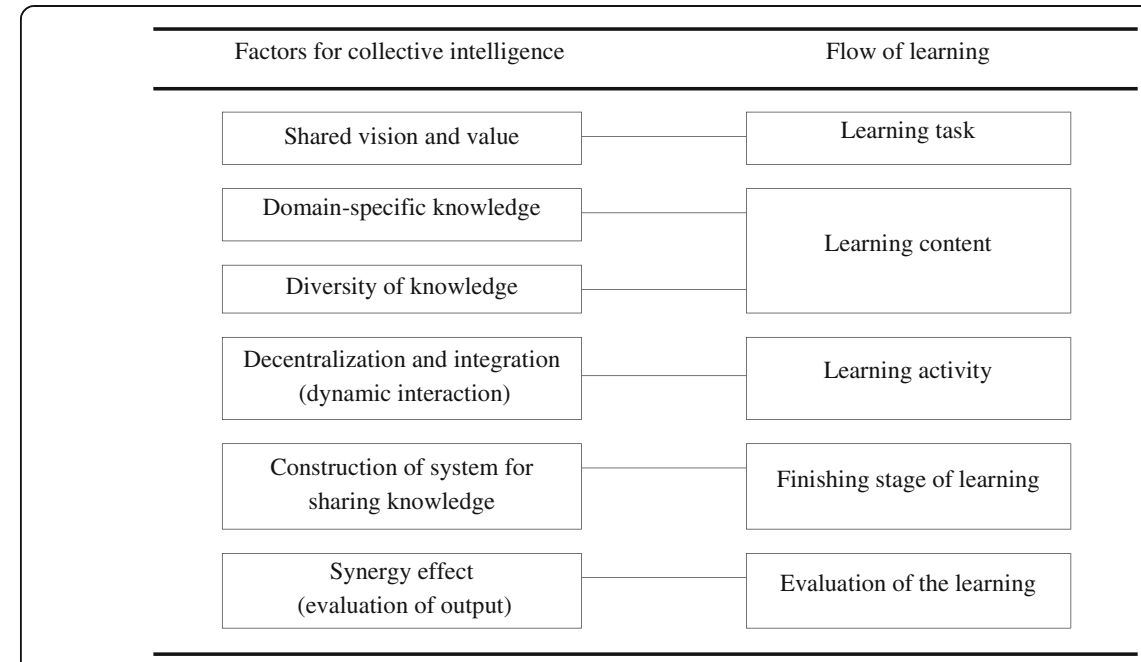

Fig. 1 The relationship between the factors for collective intelligence and the learning process

cooperation rather than competition. Accordingly, the collective intelligence attributes and the characteristics of the GI model were compared (Table 4). The GI model is suitable for acquiring higher level knowledge. In addition, this way of solving the problem is consistent with the properties of collective intelligence, except that there is no system that involves things such as continuous sharing of knowledge and evaluation of usability for output in collective intelligence. Therefore, this collaborative learning approach is sufficient to strengthen competency in acquiring and utilizing the professional and complex knowledge discussed in collective intelligence.

This study deals with the knowledge necessary to utilize advanced scientific instruments and to accumulate and share them. This will lead to the evaluation of usability about output of scientific inquiry by obtaining precise and accurate data with advanced laboratory equipment. Through this class, gifted students will have the experience of

Table 4 Comparison of GI model and collective intellectual attributes

\begin{tabular}{lll}
\hline Element & Gl model & Collective intelligence \\
\hline Attribute of task & Challenging and open issues & A practical, complex problem \\
Diversity & Categorization of different subtopics & Cognitive diversity \\
Independence & Grant learning control to students & Autonomy, openness, independence \\
Ensure autonomy in deciding on learning topics & \\
$\begin{array}{l}\text { Continuous } \\
\text { knowledge }\end{array}$ & & Collective memory \\
Cooperation & Focus on inquiry & Build a system to accumulate and share \\
system & Emphasize cooperation between subgroups & knowledge \\
& $\begin{array}{l}\text { Subdivision of the assignment and subgroup } \\
\text { contributes to problem solving of whole group }\end{array}$ & Social networking \\
& Intellectual and social interaction & \\
Output & Information gathering, cooperation, organization & Clarification in learning situation and in \\
& $\begin{array}{l}\text { and clarification of knowledge in learning context } \\
\text { Acquire high-level knowledge }\end{array}$ & various and complex situations \\
Evaluation about & & \\
the output & & Synergy effect \\
\hline
\end{tabular}


collectively producing knowledge that can utilize the equipment by integrating the subgroups of knowledge and approaching a variety of topics centered on each spectrometer. Therefore the GI model was introduced to the ALE class that had already been developed (Jeon et al. 2016). This was defined as the GI-ALE model.

In the chemistry classroom, the instructional strategies were derived based on the six factors for collective intelligence. First, a group needs to be as homogeneous as it is heterogeneous to share the common vision and values of its members (Surowiecki 2005). Science high school students have a self-directed learning ability, hopes for a career in science and engineering and a high willingness to commit to scientific inquiry learning. Therefore, it is desirable for them to carry out tasks of high interest for the learners so then the students can be motivated. They will learn to be able to autonomously control their learning.

Performing open inquiry is an activity that can be associated with creative thinking (Meador 2003; Park 2004). Scientific inquiry is an important experience that utilizes knowledge and that strengthens the scientific inquiry capacity. This is because it requires elaborating on the problems that arise in the inquiry process or flexibly considering the factors or conditions that affect the problem. In this study, through the ALE class, the students were able to perform open inquiry to reconstruct knowledge by accessing it from experimental and technological viewpoints. Complex instruments are not easy to manipulate or experiment with via trial and error, so experience or practice is required in advance. Experience with learning about these instruments allows teachers to increasingly acquire tacit knowledge for themselves than can be delivered to students, thus combining different pieces of knowledge to draw out new ideas.

Second, collective intelligence is based on expertise and requires domain-specific knowledge. Therefore, learners need to acquire more practical than theoretical knowledge. In other words, the growth of knowledge based on the integrated process of theory and practice is regarded as the acquisition of appropriate knowledge, which is closely related to the acquisition of competence (Moon, 2015). Here, practical knowledge, such as technology required in a specific domain, should be able to have a decisive influence on the creation of output. Therefore, the use of high-tech scientific instruments is very important for securing expertise in science.

Third, diversity is emphasized in collective intelligence. Learners should be given the opportunity to access a variety of knowledge. In science education, it is also important to acquire experimental knowledge as well as theoretical knowledge. In particular, gifted students are interested in the use of high-tech scientific instruments (Jeon et al. 2016). By focusing on device utilization, various experimental topics can be easily accessed. As a result, the students will be able to acquire high-level experimental techniques that can allow them to utilize the device appropriately for any subject.

Fourth, collective intelligence builds on a collective memory system to accumulate the knowledge produced by the group. It is necessary for the learners to construct a system in which the members can share their knowledge and experience so then they can carry out high-level tasks and use the results as the data for other tasks. A good way to do this is to utilize a school homepage that is available to all students.

Fifth, collective intelligence is a dynamic interaction that is decentralized and integrated. In the classroom, it is necessary to design a class that can encourage the 
students to actively participate. Thus the teachers need strategies that emphasize individual responsibility by setting a wide range of learning goals and assigning roles to all learners. In addition, it is necessary to design lessons so then collaborative work can be done well by presenting tasks that are connected organically between the subgroups. The learners should then share the results with each other. It is also necessary to plan activities that give the students the opportunity to cope with the problems that happen in a learner-centered activity. They should also give autonomy to the learners as much as possible. It is also necessary to plan activities where the students have the opportunity to improvise when they run into problems that happen in a learner-centered activity. First of all, it is important to create an environment that can dynamically expand the interactions by involving things such as learning space, learning time, SNS utilization and the expansion of learning resources.

Sixth, the outputs discussed in collective intelligence are very useful for evaluation. Once the abovementioned elements are set up, the group will naturally generate synergy through useful products. In the classroom, we can then reflect on what has been learned. In other words, the evaluation of the output and the reflection of the learner becomes important. The learner reflects on the learning process in the process of sharing and evaluating the learning outcomes. Reflection is maximized in the process of reconstructing manually the accepted information in its own way. Therefore, the production of the output is completed through the process of rebuilding according to the order, importance, and form of the information that is received variously and rebirthed in its own way. In this way, the students' reflection is important in terms of finding out for themselves why they are learning. In addition, this is a process of steadily resetting the learning direction based on thinking about how the outputs will be used in the future. In this study, we decided to focus on the correction and supplementation method through the evaluation of the group because the output is obtained in a school classroom activity. In this way, we extracted and summarized the teaching and learning elements that can correspond with the instructional strategies based on collective intelligence (Table 5).

\section{Validation of GI-ALE model}

GI-ALE model consisted of seven steps and classes based the GI-ALE model means that there are seven regular lessons per spectrometer. Some of activities in the seven steps took place outside of regular lessons. Therefore, this model was conducted over 4 weeks using regular classes and additional time. In the first lesson, orientation was conducted and the students were instructed about the operation of the GI-ALE classes. During the 4 weeks of GI-ALE class, in addition to regular class hours, we opened up two science labs at lunch and dinner times and whenever there was a student request so that further experiments could be done. During the regular class time there were discussions on the preliminary research and experimental results stages. The data collection, inquiry planning and report writing were conducted outside the regular class hours. The outputs of collaborative learning were reflected in performance assessments.

This class was aimed at individual students who, rather than solving problems individually, formed subgroups and solved them together complementarily. The teacher continuously communicated and interacted with the students as a member 
Table 5 Extraction of teaching learning elements from instructional strategies based on collective intelligence

\begin{tabular}{|c|c|c|}
\hline $\begin{array}{l}\text { Factors for collective } \\
\text { intelligence }\end{array}$ & Instructional strategies & Teaching learning elements \\
\hline $\begin{array}{l}\text { Shared vision and } \\
\text { value }\end{array}$ & $\begin{array}{l}\text { Learners are highly motivated to perform } \\
\text { tasks based on their interests } \\
\text { Activities needed for science and } \\
\text { engineering career } \\
\text { Intrinsic motivation } \\
\text { Set the purpose of group activity by } \\
\text { learners } \\
\text { Ensure students have autonomous learning } \\
\text { rights }\end{array}$ & $\begin{array}{l}\text { Applied to experimental subject (e.g., } \\
\text { chemistry experiment) } \\
\text { Open inquiry experiment activity }\end{array}$ \\
\hline $\begin{array}{l}\text { Domain-specific } \\
\text { knowledge }\end{array}$ & Select practical and practical tasks & $\begin{array}{l}\text { Utilizing advanced scientific experiment } \\
\text { equipment } \\
\text { Use real-life materials and cutting-edge } \\
\text { science }\end{array}$ \\
\hline $\begin{array}{l}\text { Diversity of } \\
\text { knowledge }\end{array}$ & $\begin{array}{l}\text { Pursue the diversity of useful knowledge } \\
\text { such as scientific concepts and } \\
\text { experimental techniques necessary for } \\
\text { scientific activities }\end{array}$ & $\begin{array}{l}\text { By organizing a small group in the } \\
\text { classroom, perform independent } \\
\text { experiment for each group }\end{array}$ \\
\hline $\begin{array}{l}\text { Construction of } \\
\text { knowledge-sharing } \\
\text { system }\end{array}$ & $\begin{array}{l}\text { Share learning outcomes and use them as } \\
\text { materials for other tasks } \\
\text { Open a cafe or use a homepage to build a } \\
\text { system where all members can share their } \\
\text { knowledge and experience }\end{array}$ & $\begin{array}{l}\text { Online use; all subgroups carry all the } \\
\text { reports on the school homepage }\end{array}$ \\
\hline $\begin{array}{l}\text { Decentralization and } \\
\text { integration (dynamic } \\
\text { interaction) }\end{array}$ & $\begin{array}{l}\text { Class objectives are the same, but use a } \\
\text { broader range of learning objectives } \\
\text { Leaners are given autonomy to participate } \\
\text { independently in decision making } \\
\text { Emphasize collaboration by organically } \\
\text { connecting tasks among subgroups } \\
\text { Build trust based on the responsibility of } \\
\text { each learner } \\
\text { Develop agility through opportunities to } \\
\text { improvise the problems that occur in } \\
\text { learner-centered activities } \\
\text { Make an environment to exchange } \\
\text { learners' knowledge, experience, } \\
\text { information, opinions, and dynamic } \\
\text { interaction such as knowledge connection } \\
\text { (Learning space, learning time, SNS } \\
\text { utilization, expansion of learning resources, } \\
\text { etc.) }\end{array}$ & $\begin{array}{l}\text { Set a wide range of learning goals } \\
\text { Give cooperative interdependence } \\
\text { Create collective report: Learning } \\
\text { outcomes used as a preparation for } \\
\text { performance assessment } \\
\text { Grant small subgroup selection option } \\
\text { Opening of laboratory and advanced } \\
\text { science laboratory } \\
\text { Activity period secured at least one month } \\
\text { per device } \\
\text { The basic experiment is to prepare the } \\
\text { students themselves } \\
\text { Present the content of pre- and post- } \\
\text { experiment reports }\end{array}$ \\
\hline $\begin{array}{l}\text { Synergy effect } \\
\text { (evaluation of } \\
\text { usability of output) }\end{array}$ & $\begin{array}{l}\text { Students have the opportunity to reflect on } \\
\text { individuals and groups } \\
\text { Reconfigure the results of other subgroups } \\
\text { in their own way } \\
\text { Internalization of knowledge } \\
\text { Expand students' own experience } \\
\text { Rules or rewards for fulfilling responsibilities }\end{array}$ & $\begin{array}{l}\text { Evaluate the result reports obtained } \\
\text { through integration between subgroups } \\
\text { and between classes and revise and } \\
\text { complement them } \\
\text { Lead them to develop new inquiry tasks } \\
\text { Organize learning content in own way } \\
\text { Performance assessment }\end{array}$ \\
\hline
\end{tabular}

of a community where the teacher was learning together with the students. Table 6 shows the specific details of the GI-ALE class focused on the use of the IR spectrometer.

The first period was the orientation time for the chemistry experiment class operation. Collective learning related to the use of advanced laboratory equipment was conducted together with the guidance of performance assessments. Since most of the students participating in the research were students who were familiar with the subgroup activities, the subgroups were freely composed based on the students' wishes. The subgroup chose one of the experimental subjects related to the IR spectrometer. 
Table 6 Content of Gl-ALE class (focused on IR spectrometer)

\begin{tabular}{|c|c|c|}
\hline Step of Class & Content of lesson & Period \\
\hline 1. Announce learning goals & $\begin{array}{l}\text { Presenting comprehensive and challenging topics through the } \\
\text { use of advanced scientific experiment equipment } \\
\text { Let's utilize an IR spectrometer. } \\
\text { Orientation, experimental activities, and performance evaluation } \\
\text { guide, reconstruction of textbook content }\end{array}$ & $1 \mathrm{st}$ \\
\hline $\begin{array}{l}\text { 2. Group composition and } \\
\text { selection of sub-topic }\end{array}$ & $\begin{array}{l}\text { Form } 4 \text { subgroups ( } 4-5 \text { people) } \\
\text { Depending on the students' level, the teacher presents the } \\
\text { information about the } 4 \text { experiments of sub topics (See Table 1.) }\end{array}$ & \\
\hline $\begin{array}{l}\text { 3. Data collection and } \\
\text { planning an inquiry }\end{array}$ & $\begin{array}{l}\text { Establish an experimental plan from chemistry experiment } \\
\text { textbooks, experimental data, online data, etc. }\end{array}$ & $\begin{array}{l}\text { Activities } \\
\text { outside of } \\
\text { class }\end{array}$ \\
\hline $\begin{array}{l}\text { 4. Presentation of pre-report } \\
\text { written in group unit }\end{array}$ & $\begin{array}{l}\text { Presentation of investigation report about experiment written } \\
\text { before writing the result report } \\
\text { Explore information from various sources, organize and record } \\
\text { collected materials, review and supplement with peers and } \\
\text { teachers }\end{array}$ & 2nd, 3rd \\
\hline 5. Conduct inquiry & Independent experiment using IR spectrometer by subgroup & 4th, 5th \\
\hline $\begin{array}{l}\text { 6. Creating report in group } \\
\text { unit }\end{array}$ & $\begin{array}{l}\text { Reconstruction and clarification of scientific knowledge through } \\
\text { experimental activities related to the topic of inquiry } \\
\text { Not created individually } \\
\text { Use Excel to organize experiment data }\end{array}$ & $\begin{array}{l}\text { Activities } \\
\text { outside of } \\
\text { class }\end{array}$ \\
\hline $\begin{array}{l}\text { 7. Sharing and evaluating } \\
\text { learning outputs }\end{array}$ & $\begin{array}{l}\text { Sharing knowledge online on school homepage } \\
\text { Cooperative learning; reflection and evaluation of experimental } \\
\text { process, positive interaction between subgroups } \\
\text { Sharing various chemical knowledge using seminar method } \\
\text { Performance assessment }\end{array}$ & $\begin{array}{l}\text { 6th, } 7 \text { th } \\
\text { Activities } \\
\text { outside of } \\
\text { class }\end{array}$ \\
\hline
\end{tabular}

When the students wrote the preliminary report, the teacher carefully instructed the students to examine the unusual items or terms of the experiment and they then instructed them to write them together. For example, in the nitrobenzene synthesis experiments, the students needed to be able to investigate the activities using new tools or equipment related to organic synthesis experiments, such as the use of a cooler, vacuum rotary evaporator, and aspirator vacuum filtration.

In the second and third period, the students presented a 20-min preliminary report on the theoretical background and method for each subgroup's experiment that was decided on in the second period. At this time, some of the contents of the preliminary report were revised and supplemented by their colleagues and teachers. While the subgroups were presenting, the rest of the subgroups were asked to listen to the presentations and to complete the assigned worksheets.

In the fourth and fifth period, experiments on each subject were carried out. The major reagents and experimental tools were prepared for each subgroup but the students were able to find and use the appropriate materials and tools needed for the experiment. They were asked to take photographs related to the experiment activities or to modify the experimental methods more precisely when the final report was written in the group unit. 
The sixth and seventh period were presented and discussed in the same way as the second and third period during the class time. On the school homepage, a menu titled "using advanced laboratory equipment" was added. The final group report, which was the result of the lesson, was posted on the school homepage and all 16 subgroups of the four classes were able to share their output. This is an online activity that considers collective memory system and social networking as one of the attributes of collective intelligence. Finally, the teacher did a performance assessment.

In the GI-ALE class, there were many experimental instruments and high-tech scientific experimental instruments. Most of the experimental materials and experimental tools were composed of open-minded inquiry activities that the students prepared directly. Therefore, this class had a variety of dynamics in its interactions, including between the teacher, student, subgroups and class, in and out of the class setting as a whole. In addition, the class acquired expert knowledge of high-tech scientific instruments and integrated knowledge in a collective form. Such dynamism is considered to be a driving force for self-directed learning activities while giving a new value to learning.

The following is an analysis of the qualitative data obtained by applying the model to increase the validity of the developed model. The discussion was divided into five parts: Domain-Specific Knowledge, Diversity of Knowledge, Decentralization and Dispersed Leadership, Integration (Dynamic Interaction) and the Synergy Effect (Evaluation of Output).

\section{Domain-specific knowledge}

The knowledge gained using a spectrometer is special knowledge in the field of science. Generally, an accurate understanding of a particular concept can be gained from the use of a particular product or equipment, as it can provide an opportunity to expand the range of learning and access various knowledge. Thus, the equipment was easier to learn with their colleagues help.

S1: I can easily learn about difficult devices with my friends and this means that I can go to college easily without confusion.

S2: I have had a good experience when dealing with advanced experimental instruments that I did not know well. I learned about the organic chemistry part as I had difficulty with in my favorite experiment.

S3: It was burdensome to carry out the experiment without understanding the principles of the device, but it seemed that my understanding of the theory increased when I studied the knowledge learned by using the device during the self-time study.

The above data are consistent with the results of the ALE class in Jeon et al.'s (2016) study, which showed that students were more likely to understand the content of the study while using the device directly. The use of high-tech scientific instruments seemed at first to be complicated and difficult, but became more comfortable over time. As mentioned, to promote the understanding of the content in organic chemistry, it deepened learning. This precise understanding of a particular concept can be gained through a variety of practical experiences, such as using the product or running the equipment. This 
expands the breadth of learning and it provides access to diverse knowledge. Knowledge based on advanced equipment, will be able to lead to scientific expertise.

\section{Diversity of knowledge}

As shown earlier in Table 1, four experiments that could utilize IR spectroscopy in the class were presented. The four groups conducted the experiment one by one and the whole group through seven steps of ALE class shared the four experiments. In addition to the knowledge of IR spectroscopy, the students will also be able to learn a variety of knowledge about the synthesis of several polymers, aspirin and nitrobenzene.

S4: It was a burden for us to have to present our learning materials but it was an opportunity to accumulate more experience and knowledge.

S5: It seems that there is a difference when I study knowledge outside of the textbook. When I studied the textbook knowledge, I did not know that it was convergent. When I studied knowledge outside of the textbooks, I seemed to be able to demonstrate my self-directed learning ability. I have learned many things because I was looking for a wide and deep study on photocatalysts while visiting international Internet sites.

As it can be seen above, the students had a positive learning attitude about expanding their learning while acquiring knowledge and experience related to the equipment. This process involved the various interactions among the topics, thus various types of learning emerged for the students even though they had not intended exploring foreign materials.

\section{Decentralization and dispersed leadership}

The following shows that during the GI-ALE class, a leader in the subgroup was changed in some of the activities. Because these activities are a professional and complex task, it can be seen that the students' roles are decentralized. It can also be seen that the students were reassigned to appropriate roles depending on the situation.

\section{S7: Our first experiment was the synthesis of nitrobenzene (which is notoriously} synthetic). When I first experimented in class, nitrobenzene was not synthesized and only benzene was detected on the IR spectrometer. After school, the students in our team re-experimented with the nitrobenzene synthesis and I decided to take a little bit of nitrobenzene from the synthesized material because I could handle the IR spectrometer. I measured it with two friends. Two of them were aspirin synthesis experiments and I gave a brief explanation of our experiments. The second time, I was glad that the synthesis was good.

The above data is a good example of whether a person voluntarily and faithfully conducted a task in the class. It also shows that the proper role allocation has been well done in each case. One particular student does not lead the overall performance. There were many students who tried again when they failed. This is because IR spectroscopy was used to confirm the synthesis of the substance. In this case, the students grasped the problem to some extent and there was no fixed time. Therefore, it can be seen that 
the roles were dispersed in order to be more efficient. S7 conducted in-depth interviews because $\mathrm{S} 7$ had the confidence that they could handle the IR spectrometer alone.

T: Did you take charge of measuring using the IR spectrum in the second experiment?

S7: When I took a class in analytical instruments during the first grade winter vacation, the most interesting device that I learned about was the IR spectroscope. It was fun to identify a specific frequency with a very small amount and it was interesting to try to find out what kind of sample it was.

T: That means you're getting used to it, aren't you?

S7: I was so impressed at that time that I immediately put the content of the class on my blog. I thought that I would become a teacher for an unspecified reader.. . Recently I was asked about my post, asking for the name of the device and how to use the device. I was not directly asked about Beer's law but I thought that it might be better to explain it in terms of Beer's law. It allowed me to explain what material I should use to get the baseline. I was so proud when he thanked me. When I first started using the device in the first semester of the first year, I was frustrated because I did not understand anything. Now I understand everything. A friend from another team was able to refer to my blog about IR spectroscopy. As usual, I was going to ask them questions about what I did not understand. However, at that time, I was so happy that they came to me and asked me.

In the discussion above, S7 was interested in IR and UV-visible spectrometers in the first grade. She gathered information about them and posted it on her blog to set up knowledge about the devices. It is not easy to handle ALE only once or twice. However, as $\mathrm{S} 7$ became interested in the device, she often used the device in order to try to get used to it. As a result, she gained expertise in the devices that could differentiate her from other students. She also served as a student leader in the use of IR spectroscopy by revealing her expertise through the GI-ALE class.

Collective intelligence seeks to decentralize the leadership of the members rather with diverse knowledge and experience in order to clearly divide the work. Expertise can promote decentralization and decentralization is a good example of the advantage of facilitating problem solving (Surowiecki 2005). Collaborative activities such as communication with others should also be practiced. Experience in the flexible attitudes toward various roles, leadership in the team, and getting used to following up are also necessary. These are all necessary for the activation of collective intelligence (Jeon 2013).

\section{Integration (dynamic interaction)}

Integration can be expressed through the interaction of the members in the group. Above all, integration occurs in the final stages of activities within a small group. It refers to the mechanism by which the individual decisions of the group members are transformed into collective decisions (Surowiecki 2005). In a group, this is important as a source of knowledge creation and competitive advantage (Verona 1999). The primary source of creativity is the individual. However, dynamic interactions 
within a group are needed to solve complex problems or to innovate (Keller 2001). The following are statements related to the interactions that emerged during the integration process.

S4: I did not understand well when I used the device alone in the first grade but when I worked on the tasks together with others, I learned a lot about how to use the device practically and it remained in my memory for a long time.

S5: When writing and modifying the report, the styles and techniques used by each student were different. This helped me to communicate and solve problems while integrating it.

S6: In the process, I realized that I had to respect the ideas of my friends whose personalities did not fit well or whose opinions often conflicted with mine. I learned how to find the best answer through dialogue.

S4 used the device directly and performed the task, so it was much easier for them to understand and know how to use the device. Know-how is tacit knowledge that is learned naturally by peers who are proficient at using the device. Tacit knowledge is knowledge that cannot be understood by words but that must be experienced through direct experience. Some of the students found the equipment difficult to handle and understand at first. However, students found out that one of the best ways to solve this difficult and complicated task is to realize that collaboration is the way to go. Above all, this shows students cooperated and shared the knowledge actively because the use of high-tech scientific instruments is professional and useful in science.

The GI-ALE class used complex experimental tools such as high-end scientific experiment equipment. This naturally led to conducting a conversation in order to solve the problems encountered in the learning context. Likewise, collaborative activities such as communication and exchange with others require practice. As you get used to leadership as well as leadership in the group specifically, experience with accidental attitudes to various roles is also necessary. This is the virtue required for the activation of collective intelligence.

\section{Synergy effect (evaluation of output)}

The following is part of the data describing the final stage of the GI-ALE model. The following data relates to the performance assessment conducted after the GI-ALE classes.

S7: It was nice to experiment with new devices while planning and organizing the experiments with friends but there were many things that did not solve the ambiguous situations clearly in the experiment. In each class, it took a lot of time to find the correct answer to the review part and it became a burden to prepare for the performance assessment.

S2: There were not enough experiments that we could compare with the other team because they were not put on the homepage within the deadline. Collaborative learning is likely to be helpful when everyone is doing well. 
Because all of the reports in the subgroup were used by the other subgroups as learning materials for the performance assessment, the students needed to write the reports clearly. However, some of the students pointed out that the reports from other groups were lacking and so could not be used as references. The questionnaire results showed that most of the students felt that the class had a positive effect but they still wanted to hear a structured explanation and correct answer from the teacher. They were anxious rather than focusing on the potential capability to learn as their knowledge is rebuilt. The above data shows that in this model, groups should be careful not to lose credibility with each other because this can cause various conflicts if the activities do not go smoothly because the cooperation is not done well.

S5: During our exams, the Excel file about nitrobenzene that we summarized was good for the exam and it was fun.

The students were satisfied with the use of experimental data from their own experiments in the performance assessment. This is because the students arranged the spectra obtained from the spectrometer directly into the Excel program. The following is the data of the positive effects of using the equipment.

S5: We will be able to exactly understand the purpose of the device through investigating various inquiry topics, so then we will be able to use it appropriately if necessary.

S9: When I am planning a chemistry experiment, I can think about it and design more ways to actually experiment with it. I think that I can continue to invent creative experimental methods.

In the above case, it was confirmed that the learning outcome could be a stepping stone that can be developed to another subject. Specialization can promote decentralization and decentralization is a core element of tacit knowledge (Surowiecki 2005). Tacit knowledge is difficult to deliver and it can be learned through training and experience. Above all, students were confident that they could use the equipment and they showed their willingness to do new scientific inquiry. Integration skills are the ability to share, exchange, and combine ideas and knowledge that exist within a group. In addition, while accumulating knowledge, a knowledge sharing system that can be freely accessed at any time should be prepared. Scientifically gifted students will be able to create knowledge by carrying out autonomous inquiry using a professional experimental technique. The following statement describes how the students felt when they completed their project over 4 weeks.

S4: When we got the results after using the device, all of the members felt a sense of accomplishment.

S5: At first, I was very anxious to write down my thoughts without well-organized data and I had a lot of thoughts about what to do if I was wrong. Over time, I was more confident in my opinion. In addition, we directly created the learning 
materials for the evaluation and we thought about how we could easily convey our experiment's content. The content was naturally organized through the process of thinking gradually.

Because this class was not only an experimental process but also because the concepts of learning are complex, there were many situations outside of the class where the members gathered, discussed and retested due to the failure of the experiments. They showed a high sense of accomplishment and confidence by overcoming any encountered problems.

The group reports from the subgroups obtained from this class were shared on the homepage for easy access to the data. These were used as reference materials for the performance assessments. A system that enables the continuous sharing of data should be established so that newly produced data could also be used for future activities. Since collective intelligence is a group ability to share knowledge and produce results through interactions to solve problems that are difficult for individuals to achieve in a specific context, we believe that the process of obtaining the learning outcomes from group experiment reports in the GI-ALE class provided the students with an opportunity to acquire the attributes of collective intelligence.

\section{Conclusion and suggestions}

The GI-ALE model developed in this study is a teaching-learning model that simultaneously emphasizes both the learning process and the results as a teaching-learning strategy for chemistry subjects in science high schools. As shown in the results, the GIALE class requires the students to learn a variety of related knowledge based on the professional experimental knowledge on equipment utilization in the scientific field of science through group activities. This cooperative collaborative process also provided opportunities for individual learners and groups to engage in reflective thinking. Through this, he reconstructed knowledge in his own way and internalized it. Ultimately, it will be able to strengthen the autonomous inquiry of the students by activating their knowledge about advanced scientific experiment equipment based on the attributes of collective intelligence.

The GI-ALE class was designed to enhance the expertise and collaborative skills of the students at the student level by sharing and integrating knowledge about advanced laboratory equipment through interactions among and between the gifted students. At the school level, it was designed to strengthen the capacity of the science high school. This can be a stepping stone for students to cultivate themselves as subjective people who produce knowledge on their own.

Collective intelligence can be manifested by the grouping of individual sources through individuals with expertise interacting dynamically, sharing common vision and values, and exchanging internal and external information and ideas. This is because activities that exchange knowledge and information through group interaction are an important way of acquiring knowledge and creating new knowledge (Bunderson and Sutcliffe 2002). However, the exchange of knowledge is not effective unless the members of a group each have a certain level of expertise, even if there is active interaction.

Therefore, systematic high-tech scientific experiments such as the GI-ALE class in a science high school has gifted the students with expertise in experimental technology 
to allow them to exchange their expertise through sharing various information and ideas about science inquiry. This type of class will contribute greatly to strengthening the research capacity of inquiry. Scientists have experience as experts in exploration methods and technical aspects. Since students do not, it is not easy for the students to discover problems and to embody them in a verifiable inquiry in the same way scientist do. Experience or practice is required beforehand because the students need to master skills through training because they cannot easily manipulate complicated devices or experiment using trial and error.

Science high schools were established to nurture scientific talents that will lead the innovation of science and technology in future society by giving scientifically-gifted students the opportunity to receive high-quality science education. As a result, there are students with scientific talent and self-directed learning abilities in the special domain of science. Science high schools are equipped with various advanced laboratory equipment so then these gifted students have the opportunity to perform autonomous inquiry into the real world. Therefore systematic inquiry learning is required to experience the various attributes of collective intelligence in classes such as the GI-ALE class.

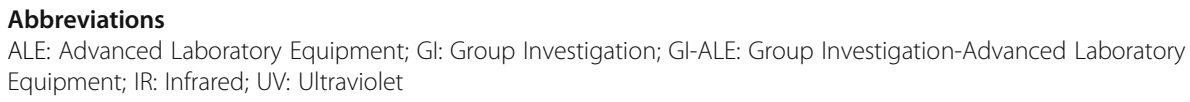
secondary science curriculum. She holds a Ph.D. in Science education (Chemistry) from Kyungpook National University at Daegu in Republic of Korea. She has been engaged in teaching science since 2003 and is currently teaching science gifted learning program, scientific inquiry and chemistry of undergraduate level at Science Gifted School.

Dahye Park is an elementary school teacher and now dispatched as a researcher at Daegu Future Education Research Institute. Her research addresses inquiry and history of science education in elementary science curriculum. She holds a Ph.D. in Science education from Kyungpook National University at Daegu in Republic of Korea. She has been engaged in teaching science since 2006 and is currently studying a policy of Daegu education at Daegu Future Education Research Institute.

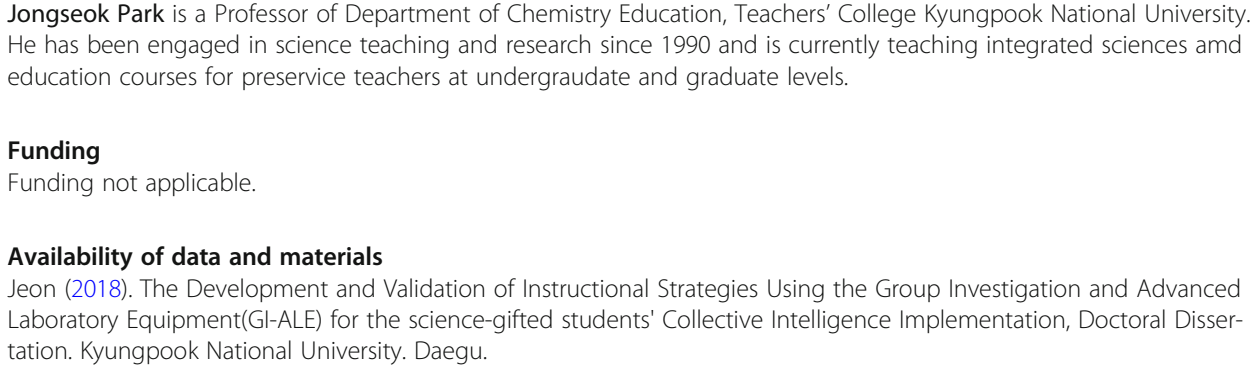




\section{Author details}

'Daegu Science High School, Daegu, South Korea. ²Daegu Future Education Research Institute, Daegu, South Korea.

${ }^{3}$ Kyungpook National University, Daegu, South Korea.

Received: 21 June 2019 Accepted: 13 November 2019

Published online: 17 December 2019

\section{References}

Bunderson, J. S., \& Sutcliffe, K. M. (2002). Comparing alternative conceptualizations of functional diversity in management teams: Process and performance effects. The Academy of Management Journal, 45(5), 875-893.

Csikszentmihalyi, M. (1999). Implications of a systems perspective for the study of creativity. In R. J. Sternberg (Ed.), Handbook of creativity. New York: Cambridge University Press.

Han, C. (2009, February). 'Collective intelligence structure' analysis. Paper presented at the 2009 Conference of the Human Computer Interaction(HCl) society of Korea. Seoul, Korea.

Hill, L. A., Brandeau, G., Truelove, E., \& Lineback, K. (2014). Collective genius: The art and practice of leading innovation. MA: Harvard Business Review Press.

Jeon, J. (2013). An exploration of current state of collective intelligence in engineering college. The Korean Journal of Educational Psychology, 27(1), 1-34.

Jeon, K. (2018). The development and validation of instructional strategies using the group investigation and advanced laboratory equipment (GI-ALE) for the science-gifted students' collective intelligence implementation, doctoral dissertation. Daegu: Kyungpook National University.

Jeon, K., Park, D., Jang, N., \& Park, J. (2016). The development and validation of instructional strategies using the advanced laboratory equipment (ALE) in science high school chemistry classrooms: A focus on UV-visible and IR spectrophotometer. Journal of the Korean Chemical Society, 60(1), 69-81.

Kao, J. J. (1997). The art \& discipline of business creativity. Strategy and leadership, 25(4), 6-11.

Keller, R. T. (2001). Cross-functional project groups in research and new product development: Diversity, communications, job stress, and outcomes. The Academy of Management Journal, 44(3), 547-555.

Kim, D. (2014). Action research for collective intelligence-based instruction using blogs and wikis in higher education. Journal of Lifelong Learning Society, 10(1), 83-111.

Kim, K. M., \& Kim, S. S. (2011). Development of a PBL-based programming instruction model using collective intelligence. The Journal of Korean Association of Computer Education, 14(2), 23-32.

Kim, K. M., Kim, S. S., Lee, I. S., \& Kang, S. G. (2010). A study on educational utilization of wiki and activation plans. The Journal of Korean Association of Computer Education, 13(2), 25-34.

Kim, S., Kim, E., \& Kim, S. W. (2013). The formation process of scientific knowledge for pre-service science teachers through collective intelligence. Journal of the Korean Association for Research in Science Education, 33(5), 963-980.

Leadbeater, C. (2009). WE-THINK: Mass innovation, not mass production. (S. Lee, trans.). Seoul: The 21 st century books (Original Work Published 2008).

Lee, H., Choi, Y., \& Ko, Y. (2014). Designing collective intelligence-based instructional models for teaching socioscientific issues. Journal of the Korean Association for Research in Science Education, 34(6), 523-534.

Lee, H., Choi, Y., \& Ko, Y. (2015). Effects of collective intelligence-based SSI instruction on promoting middle school students' key competencies as citizens. Journal of the Korean Association for Science Education, 35(3), 431-442.

Lee, Y. (2011). The development of blended instructional model of collective intelligence, doctoral dissertation. Pusan: Pusan National University.

Lee, Y. (2013). Development study of learning environment design principles and model based on collective intelligence for improving creative design ability in engineering education, doctoral dissertation. Seoul: Seoul National University.

Lee, Y., \& Lee, S. (2009). Conceptual design principles of collective intelligence. Journal of Educational Technology, 25(4), 213-239.

Lévy, P. (1994a). Collective Intelligence: Mankind's Emerging World in Cyberspace (p. 13).

Lévy, P. (1994b). Collective intelligence:For the anthropology of cyberspace. Kwon, S. (2002). Seoul: Literature and Intellectual History.

Lim, S. R., Nguyen-Phan, T. D., \& Shin, E. W. (2011). Effect of heat treatment temperatures on photocatalytic degradation of methylene blue by mesoporous titania. Applied Chemistry for Engineering, 22(1), 61-66.

Meador, K. S. (2003). Thinking creatively about science: Suggestions for primary teachers. Gifted Child Today, 26(1), 25-29.

Moon, M. (2015). The meaning of competency education in light of Polanyi epistemology, Master thesis. Seoul: Ewha Womans University.

Park, J. (2004). A suggestion of cognitive model of scientific creativity (CMSC). Journal of Science Education, 24(2), $375-386$.

Pór, G. (1995). The Quest for Collective Intelligence. In Gozdz, K. (Ed.) Community Building: Renewing Spirit and Learning in Business. Pleasanton, CA: New Leaders Press.

Sawyer, K. (2011). Group genius. 4th ed. (H. Lee, trans). Seoul: Green Cane \& Press Co (Original Work Published 2007).

Sharan, S., \& Sharan, Y. (1976). Small group teaching. NJ: Educational Technology Publication.

Sharan, S., \& Sharan, Y. (1992). Expanding cooperative learning through group investigation. NY: Teachers College Press.

Sharan, Y. (2010). Cooperative learning for academic and social gains: Valued pedagogy, problematic practice. European Journal of Education, 45(2), 300-313.

Sharan, Y., \& Sharan, S. (1990). Group investigation expands cooperative learning. Educational Leadership, 47(4), 17-21.

Song, Y. (2016). Development and construct validation of collective intelligence scale. Journal of Research in Curriculum and Instruction, 20(5), 395-406.

Surowiecki, J. (2005). The wisdom of crowds. (D. Hong \& C. Lee, Trans.). Seoul: Random House Central (Original Work Published 2004). Thelen, H. (1960). Education and the human quest. New York: Harper \& Brothers.

Verona, G. (1999). A resource-based view of product development. Academy of Management Review, 24(1), $132-142$.

Yang, M. (2010). The characteristics and mechanism of collective intelligence and its educational significance. The Journal of Yeolin Education, 18(4), 1-30. 
Yang, M. (2011). Exploring the principles of collaborative learning for realization of collective intelligence. The Korean Journal of Educational Methodology Studies, 23(2), 457-483.

Publisher's Note

Springer Nature remains neutral with regard to jurisdictional claims in published maps and institutional affiliations.

Submit your manuscript to a SpringerOpen ${ }^{0}$ journal and benefit from:

- Convenient online submission

- Rigorous peer review

- Open access: articles freely available online

- High visibility within the field

- Retaining the copyright to your article

Submit your next manuscript at $\boldsymbol{\nabla}$ springeropen.com 